\title{
IGF-I stimulates chemotaxis of human neuroblasts. Involvement of type 1 IGF receptor, IGF binding proteins, phosphatidylinositol-3 kinase pathway and plasmin system
}

\author{
A Puglianiello, D Germani, P Rossi and S Cianfarani \\ Laboratory of Paediatric Endocrinology, 'Tor Vergata' University, 00133-Rome, Italy \\ (Requests for offprints should be addressed to S Cianfarani, Laboratory of Paediatric Endocrinology, Room E-178, 'Tor Vergata' University, \\ via di Tor Vergata 135, 00133-Rome, Italy; Email: stefano.cianfarani@uniroma2.it)
}

\begin{abstract}
SH-SY5Y human neuroblastoma cells express IGF receptors, IGFs and IGF binding proteins (IGFBPs), and provide a model for studying the role of the IGF system in human neuronal development. We investigated the effect of IGF-I and des(1-3)IGF-I on the motility of SH-SY5Y cells by a cell migration assay based on the assessment of the number of cells which migrated across $8 \mu \mathrm{m}$ pore size membranes and around an agarose drop. IGF-I and des(1-3)IGF-I stimulated neuroblast chemotaxis in a dosedependent manner. Treatment of cells with these agents for $24 \mathrm{~h}$ resulted in a significant increase (IGF-I by $70 \%$ and des(1-3)IGF-I by $90 \% ; P<0 \cdot 0001)$ in cell motility relative to control conditions. Addition of monoclonal antibody against type 1 IGF receptor ( $\alpha$-IR 3 ), significantly $(P<0 \cdot 05)$ reduced the cell motility induced by IGF-I (by 30\%) and des(1-3)IGF-I (by 70\%). Wortmannin, a specific inhibitor of phosphatidylinositol (PI)-3 kinase
\end{abstract}

intracellular signalling, also reduced the IGF-stimulated cell migration (by over 40\%, $P<0 \cdot 01$ ), indicating a key role of the PI-3 kinase pathway in mediating the IGF effect on neuroblast migration. Finally, cell treatment with plasminogen (PLG) markedly enhanced neuroblast migration (by over $200 \%, P<0 \cdot 01$ ), whereas incubation with the PLG inhibitor 4-(2-aminoethyl)-benzenesulphonyl fluoride reduced cell motility (by $80 \%, P<0 \cdot 01$ ), thus suggesting an involvement of PLG-dependent IGFBP proteolysis in the regulation of neuroblast motility. In conclusion, IGF-I is a potent stimulator of neuroblast migration through the activation of type 1 IGF receptor and the PI-3 kinase intracellular pathway. IGFBPs and the plasmin system seem to play a role in cell motility, although the nature and the extent of their involvement has yet to be elucidated.

Journal of Endocrinology (2000) 165, 123-131

\section{Introduction}

The insulin-like growth factors (IGF)-1 and -II play a key role in cell cycle progression, cell proliferation and tumour progression (Humbel 1990, LeRoith et al. 1995a, Resnicoff et al. 1995). Most of the effects of IGFs are mediated by binding to type 1 IGF receptor, whereas type 2 IGF receptor is mainly involved in the clearance of IGF-II (LeRoith et al. 1995b, Stewart \& Rotwein 1996). In all biological fluids, IGFs are bound to at least six different high affinity binding proteins (termed IGFBP-1 to -6) which prolong IGF half-life, counteract the insulinlike hypoglycaemic effect of IGFs, maintain a reservoir of IGFs in the circulation, transport IGFs from the circulation to peripheral tissues, modulate IGF action, and also exert IGF-independent actions (Cianfarani \& Holly 1989, Jones \& Clemmons 1995). The complexity of the IGF system is further increased by the intervention of specific proteases which, by fragmenting IGFBPs, reduce their affinity for
IGFs and eventually lead to augmented IGF bioavailability (Hossenlopp et al. 1990, Giudice 1995).

There is increasing evidence that IGFs are also able to stimulate cell motility. Many types of cells, such as endothelial cells, keratinocytes, osteoblasts, rhabdomyosarcoma cells, epithelial cells, trophoblasts, melanoma cells, breast cancer cells, smooth muscle cells, and carcinoma cells, migrate towards a source of IGFs or display increased motility in the presence of these factors (Leventhal \& Feldman 1997). Type 1 IGF receptor has been implicated as a mediator of IGF-stimulated cell motility (Stracke $e t$ al. 1989) and signalling mechanisms involving type 1 receptor autophosphorylation, tyrosine phosphorylation of insulin receptor substrate family (IRS-1 to IRS-4), activation of phosphatidylinositol (PI)-3 kinase, integrin-dependent adhesion, and tyrosine phosphorylation of the focal adhesion proteins, such as paxillin and focal adhesionkinase (FAK), are involved in IGF-stimulated cell migration (Leventhal \& Feldman 1997). 
Neuroblastoma is the second most common solid tumour in childhood and accounts for $10 \%$ of all juvenile cancer (Brodeur \& Castleberry 1993). This malignant embryonic neoplasm is of neural crest origin and primarily consists of two cell types: $\mathrm{N}$ cells, or neuroblasts, and S cells, representing Schwann cells, epithelial cells, and melanocytes. The IGF system plays a major role in the biology of neuroblastoma (Cianfarani \& Rossi 1997). The IGFs are, in fact, intimately involved in growth (El-Badry et al. 1989, 1991) and differentiation (Recio-Pinto \& Ishii 1988, Pahlman et al. 1991) of neuroblasts acting in an autocrine (Martin \& Feldman 1993) and paracrine (Leventhal et al. 1995) fashion. In addition, we and other authors have recently demonstrated that human neuroblastoma cells are able to produce IGFBPs (Bernardini et al. 1994, Babajko \& Binoux 1996), particularly IGFBP-2, -4 and -6 , which modulate both the growthand differentiation-promoting effects of IGFs (Cianfarani et al. 1996, Babajko et al. 1997). Finally, neuroblastoma cells secrete tissue-type plasminogen activator which by transformation of plasminogen (PLG), is able to generate plasmin that acts as an IGFBP protease (Neuman et al. 1989, Lalou et al. 1994, Angelloz-Nicoud \& Binoux 1995). The addition of PLG in neuroblast cultures has recently been shown to induce IGFBP-2 proteolysis and, by reducing the IGFBP-2 affinity for IGF-II, to stimulate neuroblastoma cell proliferation (Menouny et al. 1997). Plasminogen activator is also involved in motility of neural crest cells, which produce high levels of this serine protease during their migration from the neural tube to the ventral areas of head and neck where cytodifferentiation occurs (Valinsky et al. 1985).

The SH-SY5Y human neuroblastoma cell line is an $\mathrm{N}$ cell line thought to have arisen from the neural crest (Biedler et al. 1978). SH-SY5Y cells express insulin, type 1 and type 2 IGF receptors, undergo morphological and functional neuronal differentiation when exposed to appropriate stimuli and, therefore, are often used as a model for studying neuronal development (Pahlman et al. 1990) and the interactions between the IGF system and neuroblasts (Pahlman et al. 1991, Martin \& Feldman 1993, Sumantram \& Feldman 1993, Cianfarani et al. 1996). In SH-SY5Y cells, IGFs have been shown to exert an anti-apoptotic action (Matthews \& Feldman 1996), and to induce essential steps preliminary to cell migration, such as actin polymerization and membrane ruffling with protrusion of the cell leading edge (Lauffenburger \& Horwitz 1996, Leventhal et al. 1997). This IGF action on cell architecture is inhibited by the addition of wortmannin, a fungal toxin that selectively blocks PI-3 kinase activity (Kotani et al. 1994).

In the present study we have investigated the effect of IGF-I on the motility of SH-SY5Y human neuroblastoma cells, and the role of type 1 IGF receptor, IGFBPs, plasminogen, and PI-3 kinase in the IGF-stimulated neuroblast migration.

\section{Materials and Methods}

\section{Cell culture}

Human neuroblastoma SH-SY5Y cells were cultured in minimum essential medium (MEM) (Gibco, Grand Island, NY, USA) supplemented with 10\% FCS (Gibco) in the presence of $2 \mathrm{mM}$ glutamine, $100 \mathrm{IU} / \mathrm{ml}$ penicillin, and $50 \mu \mathrm{g} / \mathrm{ml}$ streptomycin. Cultures were maintained in a humidified incubator at $37{ }^{\circ} \mathrm{C}$ with $5 \% \mathrm{CO}_{2}$ atmosphere. At the end of the exponential growth phase $(72 \mathrm{~h}$ doubling time), cells were dispersed using $0.02 \%$ EDTA (Sigma, St Louis, MO, USA). In each assay, FCS-free RPMI 1640 with glutamine was used.

IGF-I and des(1-3)-IGF-I were from GroPrep (Adelaide, Australia), the anti type I IGF receptor monoclonal antibody, $\alpha$-IR3, was purchased from Calbiochem (San Diego, CA, USA). To inhibit IGF binding to insulin receptor, we used the monoclonal antibody, MA-10, kindly supplied by Dr G Sesti, Department of Internal Medicine, 'Tor Vergata' University, Rome (Forsayeth et al. 1987). The antiproliferative factor, cytosine arabinoside (Ara-C), was purchased from PharmaciaUpjohn (Bridgewater, NY, USA). The optimal Ara-C concentration for inhibiting cell proliferation was determined by sulphorhodamine $\mathrm{B}$ assay, and preliminary experiments revealed that Ara-C maintained its inhibitory effect on DNA synthesis for $48 \mathrm{~h}$ and had no effect on cell motility. Tissue culture flasks and multiwell plates were purchased from Falcon (Lincoln Park, NJ, USA). For migrating assay cell culture, polyethylene tenephthalate (PET) inserts with $8.0 \mu \mathrm{m}$ pore size and $1.0 \times 10^{5}$ pores/ sq.cm (Falcon) were used; the inserts were put into 6-well plates. Wortmannin, PLG and 4-(2-aminoethyl)benzenesulphonyl fluoride (plasminogen inhibitor, Pc) were obtained from Sigma.

\section{Migration assay with cell culture inserts}

Migration assay was a modification of Harvath's method (Harvath et al. 1980). Cells (at or near confluency) were dispersed with $0.02 \%$ EDTA and replated in culture inserts in serum-free medium. The final cell density was assessed by a haemocytometer, counting the viable trypanblue excluding cells. The lower wells of the 6-well plates were loaded with $3 \mathrm{ml}$ RPMI 1640 containing Ara-C $(625 \mathrm{ng} / \mathrm{ml})$. The cell culture inserts were placed over the 6-well plates and loaded with $1.5 \mathrm{ml}$ RPMI 1640 plus Ara-C $(625 \mathrm{ng} / \mathrm{ml})$ and containing $4.5 \times 10^{5}$ cells. After 24-h incubation at $37^{\circ} \mathrm{C}$ to allow the cell attachment to the insert membranes, IGF-I (1 to $100 \mathrm{nM}$ ) and des(1-3)IGF-I (1 to $100 \mathrm{nM}$ ) were added in the lower wells. In some assays, cells were preincubated with $\alpha$-IR3 $(1 \mu \mathrm{g} / \mathrm{ml}), \quad$ MA-10 $\left(6.6 \times 10^{-7} \mathrm{M}\right)$ or wortmannin $(50 \mathrm{nM})$ for $60 \mathrm{~min}$ at $37^{\circ} \mathrm{C}$. PLG $(5 \mu \mathrm{g} / \mathrm{ml})$ and Pc $(0.075 \mathrm{mM})$ were added $8 \mathrm{~h}$ after the addition of IGFs. 


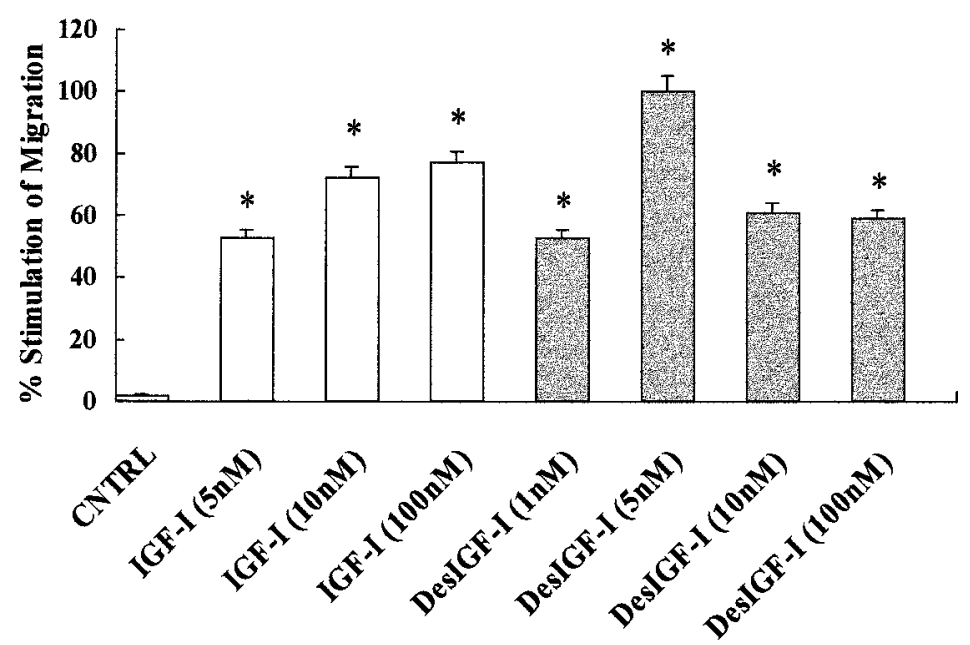

Figure 1 Migration of SH-SY5Y cells: the effect of IGF-I and des(1-3)IGF-I. Each migration stimulatory effect is compared with the response of cells to $\operatorname{des}(1-3)$ IGF-I (5 nM) in the same assay, which, eliciting the maximal response, is assigned an arbitrary value of $100 \%$. ${ }^{*} P<0 \cdot 001$ vs control. CNTRL, control.

To determine the direction of migration, cells were plated in the upper surface of the insert membranes and the IGFs were added in the lower well only, in the upper well only, or in both wells. After 24-h incubation, cells were fixed with $10 \%$ trichloroacetic acid (Sigma), and cells on the upper surface of the inserts were removed by a sterile cell scraper $(1 \cdot 8$-cm blade, Falcon), in order to leave the cells which had migrated across the membrane and which were present on the lower surface. The cells were then stained with 6\% GIEMSA (Merck KGA, Darmstadt, Germany), and membranes were removed and put on a glass slide. The number of migrated cells with whole body outside the pores was assessed in a blinded fashion by three observers who counted, with an inverted microscope fitted with a grid eyepiece at a total magnification of $\times 20$, twenty fields for each slide. All experiments were performed in triplicate and were repeated a minimum of three times.

\section{Migration assay with agarose drop}

Cell migration was visualized by measuring the extent of neuroblast migration from an agarose drop using a modified method described by Varani et al. (1978). Briefly SH-SY5Y cells were resuspended at $30 \times 10^{6} / \mathrm{ml}$ in RPMI 1640 media containing 10\% FCS and 0.3\% low melting point agarose maintained at $37^{\circ} \mathrm{C}$ to prevent setting of the agarose; $2 \mu \mathrm{l}$ of the cell suspension were applied to the centre of the wells within a 24 -well tissue culture dish (Falcon), which was than placed at $4{ }^{\circ} \mathrm{C}$ for $30 \mathrm{~min}$ to allow the agarose to solidify. Thereafter, agarose drop was covered with $0.4 \mathrm{ml}$ serum-free media and maintained for $24 \mathrm{~h}$ at $37^{\circ} \mathrm{C}$. Eventually, IGFs were added and the plate maintained at $37^{\circ} \mathrm{C}$ for $24 \mathrm{~h}$. Photomicrographs of the agarose drop assay were taken after 24-h incubation.

\section{Statistics}

Differences of means of at least three different experiments performed in triplicate and read by three independent observers were assessed using one-way analysis of variance (ANOVA). Significance was assigned for $P<0 \cdot 05$. A computer program was used for all statistical calculations (BMPD, statistical software, SOLO 3.0, Los Angeles, CA, USA).

\section{Results}

\section{IGFs stimulate migration of SH-SY5Y neuroblasts}

IGF-I significantly stimulated neuroblast migration in a dose-dependent manner, increasing cell motility by over 70\% (P<0.0001). Des(1-3)IGF-I, an IGF-I analogue five to ten times more potent than IGF-I in stimulating DNA and protein synthesis because of its lower binding affinity for IGFBPs, was significantly more potent than IGF-I in enhancing cell motility (Fig. 1). The migration promoting effect of des(1-3)IGF-I was observed at concentrations as low as $1 \mathrm{nM}$ and reached a peak at a concentration of $5 \mathrm{nM}$ (more than 90\% increment), with a reduction at higher concentrations, thus suggesting a chemotactic action. At low concentrations of a chemoattractant, no cell movement occurs. At higher concentrations, the cells are able to distinguish a difference in the concentration gradient of substance, and thus move in a directed fashion. At still 
higher concentrations, the gradient is no longer distinguishable and the cell does not move towards the chemoattractant. The potent effect of des(1-3)-IGF-I on cell migration suggests that IGFBPs may inhibit IGFstimulated cell motility. The IGF stimulatory action on cell motility was independent of the mitogenic action, since cell proliferation was blocked by the addition of the DNA polymerase inhibitor, Ara-C. The IGF stimulatory effect on neuroblast motility was confirmed by the agarose drop assay (Fig. 2).

\section{Type 1 IGF receptor mediates the IGF-induced cell migration}

The addition of the monoclonal antibody, $\alpha$-IR3, which specifically inhibits IGF binding to type 1 IGF receptor (IGF-IR), induced a significant reduction of both IGF-I(by approximately $30 \%, P<0 \cdot 05)$ and $\operatorname{des}(1-3)$ IGF-Iinduced cell migration (by approximately $70 \%, P<0 \cdot 05$ ), thus suggesting that most of the IGF effect on neuroblast motility is mediated by the activation of IGF-IR (Fig. 3). We also tested the effect of the inhibition of insulin receptor on neuroblast migration using the monoclonal antibody, MA-10, which failed to inhibit cell motility.

\section{The IGF-stimulated migration is directional}

To determine whether the IGF-induced cell motility is directional towards a concentration gradient of IGFs (chemotaxis) or is a random movement (chemokinesis), we performed a migration assay in which IGF-I $(10 \mathrm{nM})$ was added to the lower wells only, the upper wells only, both sets of wells, or neither. As shown in Fig. 4, the addition of IGF-I to the upper well or to both wells led to significantly less migration compared with that observed when IGF-I was present in the lower well only. These experiments demonstrated that IGF-I stimulated a primarily chemotactic response.

IGF-stimulated neuroblast migration is mediated by PI-3 kinase activation

To test whether PI-3 kinase is involved in neuroblast migration, a migration assay using its specific inhibitor, wortmannin, was performed. Wortmannin was able to reduce significantly the IGF-I- (by approximately $40 \%, P<0 \cdot 01)$ and des(1-3)IGF-I-stimulated neuroblast migration (by approximately 50\%, $P<0 \cdot 01$ ) (Fig. 5).

Plasminogen system plays an active role in IGF-induced neuroblast migration

IGFBP-2 is the major IGFBP secreted by human neuroblasts and undergoes proteolysis by PLG. To determine the role of IGFBP proteolysis in IGF-stimulated neuroblast motility, cells were treated with PLG $(5 \mu \mathrm{g} / \mathrm{ml})$ in the presence or not of its specific inhibitor pefablock
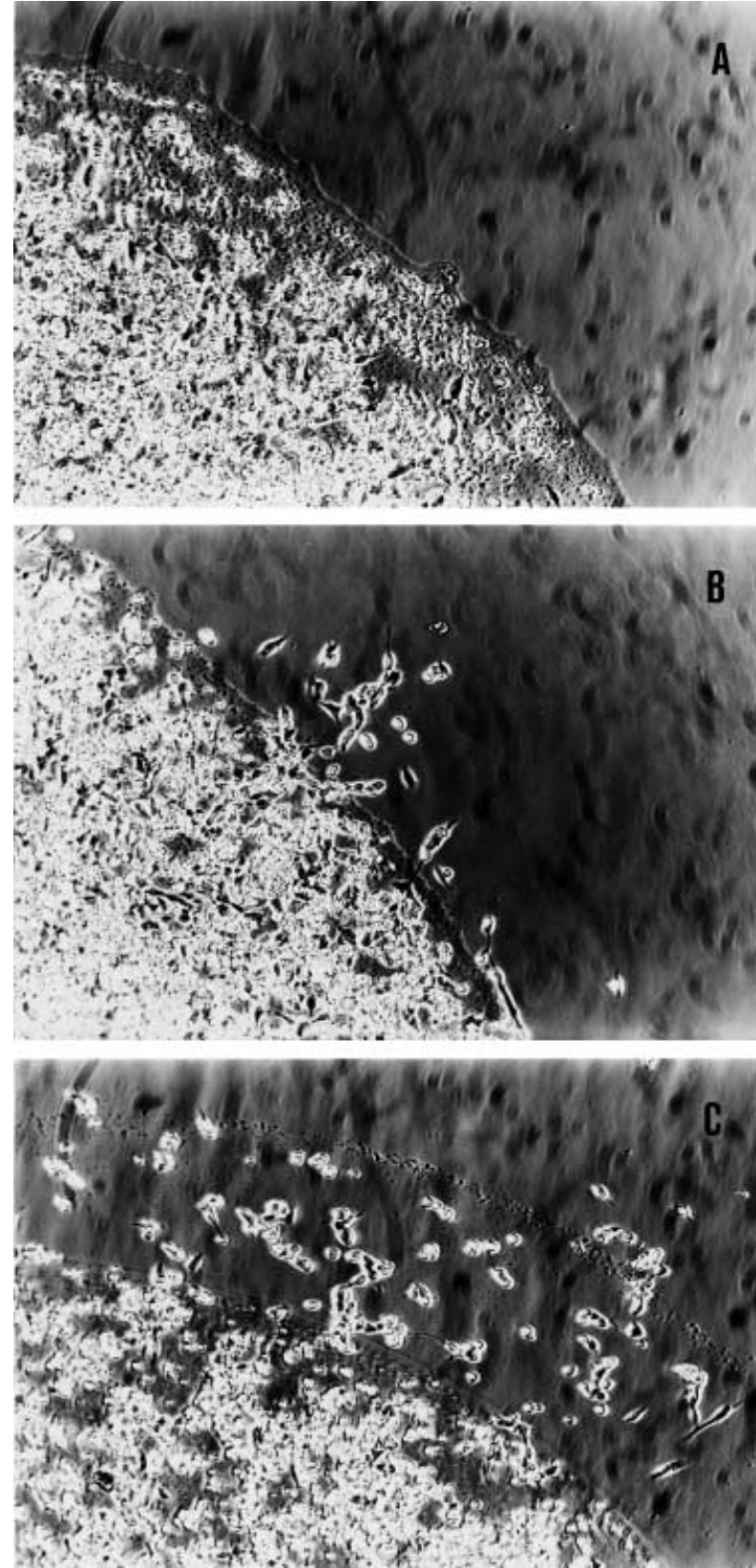

Figure 2 Agarose drop assay: the IGF stimulatory effect on neuroblast motility. SH-SY5Y cells in an agarose drop after different treatment conditions: (A) serum-free medium alone; (B) serum-free medium plus $10 \mathrm{nM}$ IGF-I, and (C) serum-free medium plus $100 \mathrm{nM}$ IGF-I.

(Pc)-SC (4-(2-aminoethyl)-benzenesulphonyl-fluoride) $(0.075 \mathrm{mM})$, a serine protease inhibitor previously shown to be innocuous to neuroblasts at this concentration (Menouny et al. 1997). PLG significantly enhanced both the IGF-I- (by approximately $250 \%, P<0 \cdot 01$ ) and des(13)IGF-I-induced (by approximately $200 \%, P<0 \cdot 01$ ) cell 


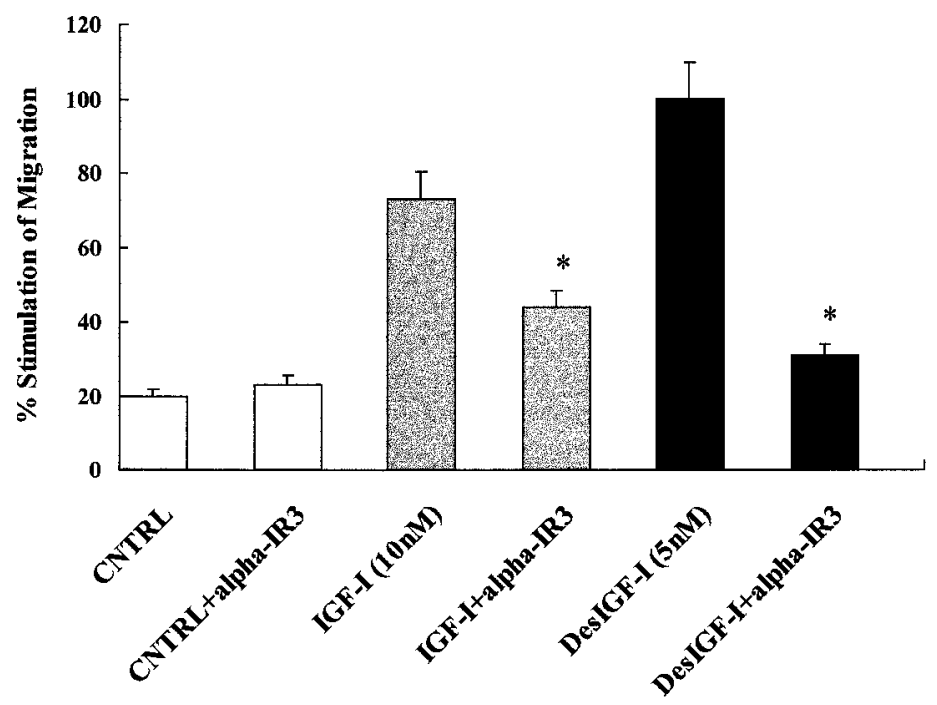

Figure 3 Inhibition of SH-SY5Y cells migration induced by the anti type 1 IGF receptor antibody, $\alpha$-IR3 $(1 \mu \mathrm{g} / \mathrm{ml})$. Cell migration in response to IGF-I $(10 \mathrm{nM})$ and des(1-3)IGF-I $(5 \mathrm{nM})$ was determined in the presence and the absence of the type 1 IGF receptor blocking antibody, $\alpha$-IR3. Taking the total number of migrated cells in response to des(1-3)IGF-I (5 nM) with no added antibody as $100 \%$ migration (maximal stimulatory effect), $\alpha$-IR3 significantly reduced the response to both IGF-I and des(1-3)IGF-I; ${ }^{\star} P<0 \cdot 05$. CNTRL, control.

migration, and this effect was reduced by preincubation with $\mathrm{Pc}$, which significantly inhibited cell motility (by approximately $80 \%, P<0 \cdot 01)$ in respect to either IGF-I or des(1-3)IGF-I, thus suggesting an involvement of PLG-dependent IGFBP proteolysis in modulating the IGF-dependent neuroblast migration (Fig. 6).

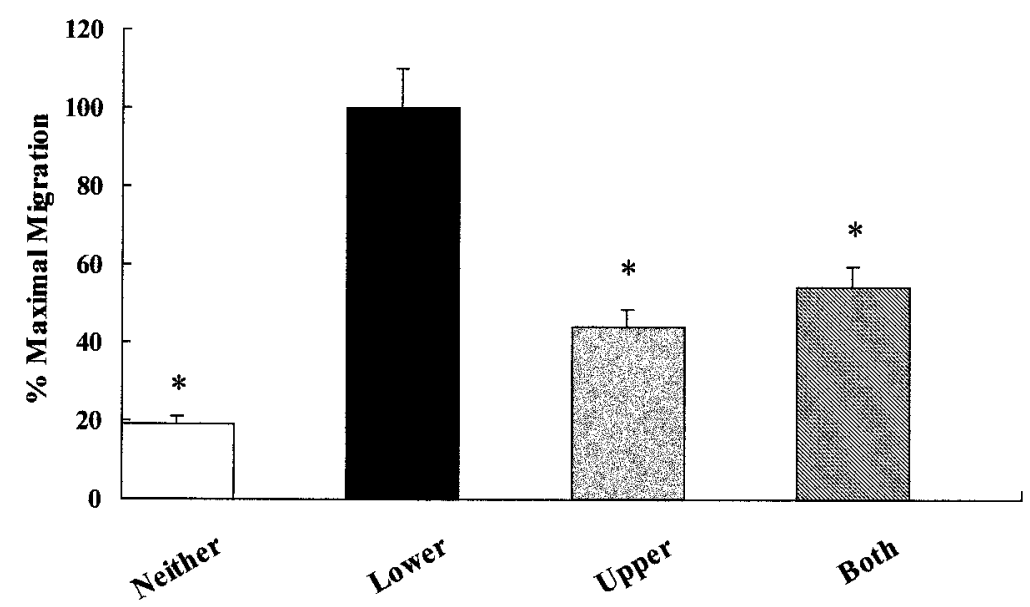

Figure 4 Directional migration of SH-SY5Y cells. The graph depicts the effects on SH-SY5Y cell migration of adding IGF-I $(10 \mathrm{nM})$ to the lower wells, the upper wells, neither well, or both wells, and was performed as described in Materials and Methods. The number of migrated cells when IGF-I was present in the lower wells only is assigned a relative value of $100 \%$ and is a measure of chemotaxis. Migration in response to the addition of IGF-I to only the upper wells or to both wells is a measure of chemokinesis, stimulation of migration in the absence of a concentration gradient. IGF-I is more potent in stimulating migration when there is a positive concentration gradient towards which the cells migrate; ${ }^{*} P<0 \cdot 01$. 


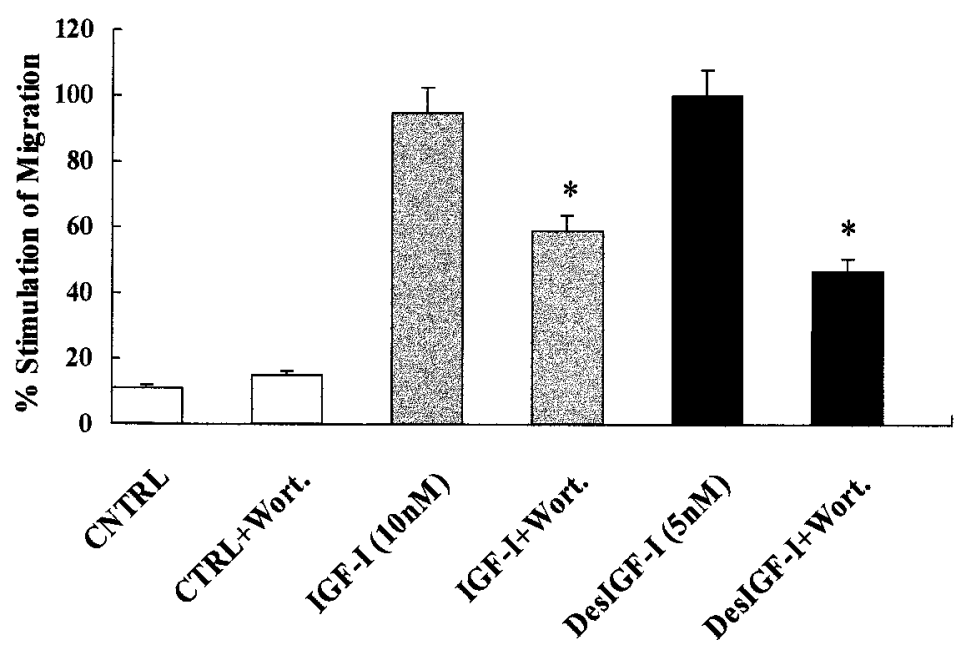

Figure 5 Inhibition of $\mathrm{SH}-\mathrm{SY} 5 \mathrm{Y}$ cells migration by wortmannin. Cell migration in response to IGF-I (10 nM) and des(1-3)IGF-I (5 nM) was determined in the presence and in the absence of wortmannin (Wort.) (50 nM), a specific inhibitor of PI-3 kinase. Taking the total number of migrated cells in response to des(1-3)IGF-I (5 nM) with no added wortmannin as $100 \%$ migration (maximal stimulatory effect), wortmannin significantly reduced the cell response to both IGF-I and des(1-3)IGF-I; * $P<0 \cdot 01$. CNTRL, control.

\section{Discussion}

We have previously reported an IGF-I growth and differentiation promoting effect in SH-SY5Y cells (Cianfarani et al. 1996); in this study we provide direct evidence that IGF-I also stimulates motility of these human neuroblasts, exerting a chemoattractant activity. This finding is consistent with the observation that IGF-I induces actin

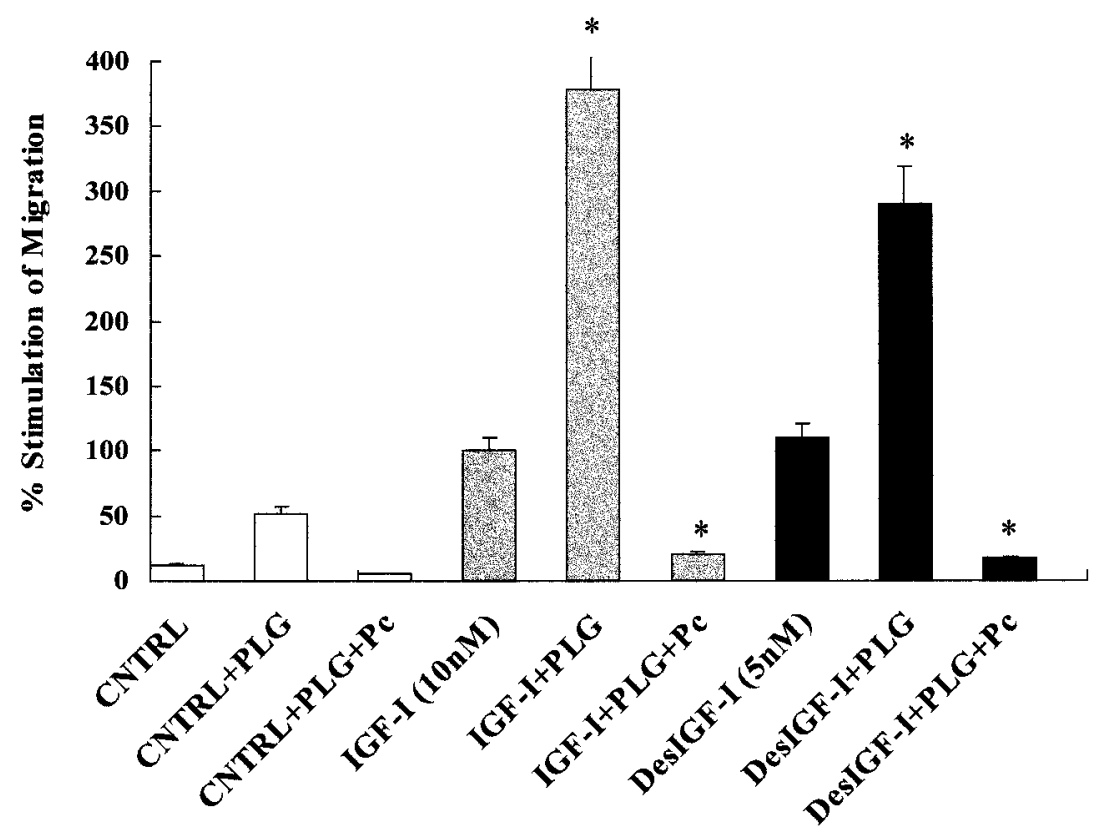

Figure 6 Effect of plasminogen on $\mathrm{SH}-\mathrm{SY} 5 \mathrm{Y}$ cells migration. Cell migration in response to IGF-I $(10 \mathrm{nM})$ and des(1-3)IGF-I $(5 \mathrm{nM})$ was determined in the presence of plasminogen (PLG, $5 \mu \mathrm{g} / \mathrm{ml}$ ) in the presence or in the absence of the plasminogen inhibitor, Pc $(0.075 \mathrm{mM})$. Taking the total number of migrated cells in response to des(1-3)IGF-I (5 nM) with no added PLG as $100 \%$ migration (maximal stimulatory effect), PLG significantly increased the cell response to both IGF-I and des(1-3)IGF-I, whereas the addition of PC significantly inhibited cell motility; ${ }^{*} P<0 \cdot 01$. CNTRL, control. 
polymerization and membrane ruffling with protrusion of the cell leading edge in these cells (Kotani et al. 1994, Lauffenburger \& Horwitz 1996, Leventhal et al. 1997). In SH-SY5Y cells, IGF-I is also known to stimulate lamellipodial advance and to promote tyrosine phosphorylation of paxillin and FAK, thus potentially playing a key role in tumour cell invasion (Leventhal et al. 1997).

Chemotaxis, a direct cell locomotion towards a soluble extracellular chemical gradient, is one of the steps necessary for migration of normal and aberrant cells. After binding of the chemokine to its receptor, various intracellular signals are generated, leading to a reconfiguration of the cytoskeleton, which is involved in the motile response. IGF-stimulated chemotaxis has been demonstrated in melanoma cells (Stracke et al. 1988), endothelial cells (Nakao-Hayashi et al. 1993), osteoblasts (Panagakos 1993), smooth muscle cells (Bornfeldt et al. 1994), breast cancer cells (Doerr \& Jones 1996), and multiple myeloma cells (Vanderkerken et al. 1999). Understanding the biochemical events that govern the neuroblastoma metastatic spread is of major importance for controlling the disease. In addition, the cell line we used is considered a reliable model for neuronal development and the comprehension of the mechanisms underlying neuroblast motility might concur to clarify the pathophysiology of the congenital neuronal migration defects, such as agyria or lissencephaly.

In our migration assay, the truncated analogue des(1-3)IGF-I, which exhibits reduced binding capacity to IGFBPs, had a greater potency to stimulate SH-SY5Y cell migration than IGF-I. This finding strongly suggests that IGFBPs inhibit IGF-induced cell migration, locally modulating the IGF-I biological action. This inhibitory role of IGFBPs on IGF-stimulated cell migration has been described in smooth muscle cells (Gockerman et al. 1995) and, indirectly, in colonic epithelial cells (Andre et al. 1999). It is noteworthy that IGFBP-1 and IGFBP-2 contain the RGD (Arg-Gly-Asp) sequence which is required for binding to membrane integrins which mediate cell-extracellular matrix adhesion (Jones et al. 1993). Human neuroblastoma cells produce essentially IGFBP-2, smaller amounts of IGFBP-4, and traces of IGFBP-6 (Bernardini et al. 1994, Babajko \& Binoux 1996, Cianfarani et al. 1996). IGFBP-2 is the major IGFBP in cerebrospinal fluid (Roghani et al. 1993), is produced in various regions of the central nervous system (Ocrant et al. 1990, Ishikawa et al. 1995) and, therefore, by binding to integrins and by modulating IGF actions may influence both cell adhesion and migration, thereby taking an active part in central nervous system fetal development and postnatal maintenance.

Most of the effects of IGF-I and -II are mediated by binding to type I IGF receptor (IGF-IR). Evidence that IGF-IR mediates the chemotactic response to IGF-I is provided by the finding that the monoclonal antibody, $\alpha$-IR3, profoundly inhibited the IGF-I-stimulated cell motility. This inhibitory effect of $\alpha$-IR 3 on SH-SY5Y cell migration is consistent with the observation that IGF-IR is a motility receptor in other cell lines such as melanoma cells (Stracke et al. 1989) and breast cancer cells (Doerr \& Jones 1996), and its block inhibits the IGF-I-stimulated lamellipodial advance (Leventhal \& Feldman 1997).

Binding of IGF-I to the extracellular $\alpha$-subunits of the IGF-IR results in autophosphorylation of the cytoplasmatic $\beta$-subunits which leads to a cascade of cellular signal transduction pathways (Van Obberghen 1994, White \& Kahn 1994). One key event is the binding of insulin receptor substrate family (IRS-1 to -4 ) to phosphotyrosine residues on the receptor $\beta$-subunits (Avruch 1998). After binding by activated receptors, insulin receptor substrates are tyrosine phosphorylated and act as docking proteins for downstream signal transduction molecules, including PI-3 kinase and the Grb2-SOS complex (Kim et al. 1998a). Recent findings indicate that the PI-3 kinase pathway is implicated in IGF-induced membrane ruffling and growth cone extension, whereas the mitogen-activated protein (MAP) kinase pathway plays a key role in IGF-induced neurite outgrowth in SH-SY5Y cells (Waters \& Pessin 1996, Kim et al. 1997). Our results show that PI-3 kinase inhibition significantly reduces the IGF-stimulated neuroblast migration, thus indicating that PI-3 kinase activation is required for neuroblast motility. However, the finding that PI-3 kinase inhibition reduces but does not abolish neuroblast migration suggests that when the main pathway (i.e. PI-3 kinase) is blocked, alternative pathways might be activated to maintain the IGFstimulated cell migration. This hypothesis is consistent with the observation that PI-3 kinase inhibitors, such as wortmannin, increase tyrosine phosphorylation of IRS-2 and its association with Grb2 in SH-SY5Y cells (Kim et al. 1998b). However, the MAP kinase pathway is unlikely to be involved in this alternative regulation of neuroblast migration since PI-3 kinase inhibitors also cause a dose-dependent inhibition of MAP kinase pathway in neuroblasts (Kim et al. 1998b).

Plasmin plays a role in regulating cell proliferation and migration during embryonic development and in tumour invasion and metastasis, affecting cell adhesion to the extracellular matrix (Valinsky \& Le Douarin 1985, Dano et al. 1985). Neuroblasts secrete tissue-type plasminogen activator (t-PA) which eventually induces the generation of plasmin (Neuman et al. 1989, Lalou et al. 1994) and, recently, plasmin-induced IGFBP proteolysis has been shown to enhance SH-SY5Y cell proliferation in response to IGFs (Menouny et al. 1997). Our results suggest that plasmin-mediated IGFBP proteolysis may increase IGFinduced neuroblast migration, thus indirectly confirming the role played by IGFBPs in modulating the cell response to IGFs and suggesting that the interaction between the IGF and plasmin system may play a pivotal role in regulating embryonic migration of neuroblasts and metastatic dissemination of neuroblastoma. However, it has to be pointed out that the addition of plasminogen also 
increases basal (not significantly) and des(1-3)IGF-Iinduced migration. At least three possible mechanisms may explain this finding: (a) plasminogen may enhance cell motility through a mechanism independent of IGFs and IGFBPs; (b) if plasminogen works specifically by degrading IGFBPs, its action in the absence of exogenous IGF-I must be due to the local secretion of IGFs; however, it remains unclear why plasminogen increases the des(1-3)IGF-I-stimulated migration to such a large extent; (c) the IGFBPs affected by plasminogen regulate motility in an IGF-independent manner.

In conclusion, IGF-I is a potent stimulator of neuroblast migration through the activation of type 1 IGF receptor and the PI-3 kinase intracellular pathway. IGFBPs and the plasmin system seem to play a role in cell motility although the nature and the extent of their involvement has yet to be elucidated.

\section{Acknowledgements}

We are grateful to Dr Roopmathy Rajah (Department of Pediatrics, University of Pennsylvania, Philadelphia, USA) for her helpful advice and comments on the manuscript.

\section{References}

Andre F, Rigot V, Remacle-Bonnet M, Luis J, Pommier G \& Marvaldi J 1999 Protein kinases $C-\gamma$ and $-\delta$ are involved in insulin-like growth factor-I-induced migration of colonic epithelial cells. Gastroenterology 116 64-77.

Angelloz-Nicoud P \& Binoux M 1995 Autocrine regulation of cell proliferation by the insulin-like growth factor (IGF) and IGF binding protein-3 protease system in a human prostate carcinoma cell line (PC-3). Endocrinology 136 5485-5492.

Avruch J 1998 A signal for $\beta$-cell failure. Nature 391 846-847.

Babajko S \& Binoux M 1996 Modulation by retinoic acid of insulinlike growth factor (IGF) and IGF binding protein expression in human SK-N-SH neuroblastoma cells. European Journal of Endocrinology 134 474-480.

Babajko S, Laneuve P, Loret C \& Binoux M 1997 IGF-binding protein-6 is involved in growth inhibition in SH-SY5Y human neuroblastoma cells: its production is both IGF- and cell densitydependent. Journal of Endocrinology 152 221-227.

Bernardini S, Cianfarani S, Spagnoli A, Annicchiarico-Petruzzelli M, Melino G, Massoud R, Boscherini B, Finazzi-Agrò A, Rosenfeld RG \& Federici G 1994 Expression and down regulation by retinoic acid of IGF binding protein -2 and -4 in medium from human neuroblastoma cells. Journal of Neuroendocrinology 6 409-413.

Biedler JL, Roffler-Tarlov S, Schachner M \& Freedman LS 1978 Multiple neurotransmitter synthesis by human neuroblastoma cell lines and clones. Cancer Research 38 3751-3757.

Bornfeldt KE, Raines EW, Nakano T, Graves LM, Krebs EG \& Ross R 1994 Insulin-like growth factor-I and platelet-derived growth factor receptor induced directed migration of human arterial smooth muscle cells via signaling pathways that are distinct from those of proliferation. Journal of Clinical Investigation 93 1266-1274.

Brodeur GM \& Castleberry RP 1993 Neuroblastoma. In Principles and Practice in Pediatric Oncology, pp 739-767, 2nd edn. Eds PA Pizzo \& DG Poplack. Philadelphia: JB Lippincott.

Cianfarani S \& Holly JMP 1989 Somatomedin-binding proteins: what role do they play in the growth process? European Journal of Pediatrics $14976-79$.
Cianfarani S \& Rossi P 1997 Neuroblastoma and insulin-like growth factor system. New insights and clinical perspectives. European Journal of Pediatrics 156 256-261.

Cianfarani S, Germani D, Rossi P, Spagnoli A \& Mercanti D 1996 Do insulin-like growth factor binding proteins (IGFBPs) modulate the IGF-I growth promoting and differentiating effects in human neuroblastoma cells? European Journal of Endocrinology 135 716-723.

Dano K, Andreasen PA, Grondhal-Hansen J, Kristensen P, Nielsen LS \& Skriver L 1985 Plasminogen activators, tissue degradation, and cancer. Advanced Cancer Research 44 139-266.

Doerr ME \& Jones JI 1996 The roles of integrins and extracellular matrix proteins in the insulin-like growth factor I-stimulated chemotaxis of human breast cancer cells. Journal of Biological Chemistry 271 2443-2447.

El-Badry OM, Romanus JA, Helman LJ, Cooper MJ, Rechler MM \& Israel MA 1989 Autonomous growth of a human neuroblastoma cell line is mediated by insulin-like growth factor II. Journal of Clinical Investigation 84 829-839.

El-Badry OM, Helman LJ, Chatten J, Steinberg SM, Evans AE \& Israel MA 1991 Insulin-like growth factor II-mediated proliferation of human neuroblastoma. Journal of Clinical Investigation 87 648-657.

Forsayeth JR, Montemurro A, Maddux BA, DePirro R \& Goldfine ID 1987 Effect of monocolonal antibodies on human insulin receptor autophosphorylation, negative cooperativity, and down-regulation. Journal of Biological Chemistry 262 4134-4140.

Giudice LC 1995 IGF binding protein-3 protease regulation: how sweet it is! Journal of Clinical Endocrinology and Metabolism $\mathbf{8 0}$ 2279-2281.

Gockerman A, Prevette T, Jones JI \& Clemmons DR 1995 Insulinlike growth factor (IGF)-binding proteins inhibit the smooth muscle cell migration responses to IGF-I and IGF-II. Endocrinology 136 4168-4173.

Harvath L, Falk W \& Leonard EJ 1980 Rapid quantitation of neutrophil chemotaxis: use of a polyvinylpyrrolidone-free polycarbonate membrane in a multiwell assembly. Journal of Immunology Methods 37 39-45.

Hossenlopp P, Segovia B, Lassarre C, Roghani M, Bredon M \& Binoux M 1990 Evidence of enzymatic degradation of insulin-like growth factor binding proteins in the $150 \mathrm{kD}$ complex during pregnancy. Journal of Clinical Endocrinology and Metabolism $\mathbf{7 1}$ 797-805.

Humbel RE 1990 Insulin-like growth factors I and II. European Journal of Biochemistry 190 445-462.

Ishikawa K, Ohe Y \& Tatemoto K 1995 Synthesis and secretion of insulin-like growth factor binding protein-2 by cultured brain meningeal cells. Brain Research 697 122-129.

Jones JI \& Clemmons DR 1995 Insulin-like growth factors and their binding protein: biological actions. Endocrine Reviews 16 3-34.

Jones JI, Gockerman A, Busby WH, Wright G \& Clemmons DR 1993 Insulin-like growth factor binding protein 1 stimulates cell migration and binds to the $\alpha 5 \beta 1$ integrin by means of its Arg-GlyAsp sequence. Proceedings of the National Academy of Sciences of the USA 90 10553-10557.

Kim B, Leventhal PS, Saltiel AR \& Feldman EL 1997 Insulin-like growth factor-I-mediated neurite outgrowth in vitro requires mitogen activated protein kinase activation. Journal of Biological Chemistry 272 21268-21273.

Kim B, Cheng HL, Margolis B \& Feldman EL 1998a Insulin receptor substrate 2 and Shc play different roles in insulin-like growth factor I signalling. Journal of Biological Chemistry 273 34543-34550.

Kim B, Leventhal PS, White MF \& Feldman EL 1998b Differential regulation of insulin receptor substrate- 2 and mitogen-activated protein kinase tyrosine phosphorylation by phosphatidylinositol 3-kinase inhibitors in SH-SY5Y human neuroblastoma cells. Endocrinology 139 4881-4889.

Kotani K, Yonezawa K, Hara K, Ueda H, Kitamura Y, Sakaue H, Ando A, Chavanieu A, Calas B, Grigorescu F, Nishiyama M, 
Waterfield MD \& Kasuga M 1994 Involvement of phosphatidylinositol 3-kinase in insulin- or IGF-I-induced membrane ruffling. EMBO Journal 13 2313-2321.

Lalou C, Silve C, Rosato R, Segovia B \& Binoux M 1994 Interactions between insulin-like growth factor-I (IGF-I) and the system of plasminogen activators and their inhibitors in the control of IGF binding protein-3 production and proteolysis in human osteosarcoma cells. Endocrinology 135 2318-2326.

Lauffenburger DA \& Horwitz AF 1996 Cell migration: a physically integrated molecular process. Cell 84 359-369.

LeRoith D, Baserga R, Helman L \& Roberts CT 1995a Insulin-like growth factors and cancer. Annals of Internal Medicine 122 54-59.

LeRoith D, Werner H, Beitner-Johnson D \& Roberts CT 1995b Molecular and cellular aspects of the insulin-like growth factor I receptor. Endocrine Reviews 16 143-163.

Leventhal PS \& Feldman EL 1997 Insulin-like growth factors as regulators of cell motility. Trends in Endocrinology and Metabolism $\mathbf{8}$ $1-6$

Leventhal PS, Randolph AE, Vesbit TE, Schenone A, Windebank AJ \& Feldman EL 1995 Insulin-like growth factor-II as a paracrine growth factor in human neuroblastoma cells. Experimental Cell Research 221 179-186.

Leventhal PS, Shelden EA, Kim B \& Feldman EL 1997 Thyrosine phosphorylation of paxillin and focal adhesion kinase during insulin-like growth factor-I-stimulated lamellipodial advance. Journal of Biological Chemistry 272 5214-5218.

Martin DM \& Feldman EL 1993 Regulation of insulin-like growth factor-II expression and its role in autocrine growth of human neuroblastoma cells. Journal of Cell Physiology 155 290-300.

Matthews CC \& Feldman EL 1996 Insulin-like growth factor I rescues SH-SY5Y human neuroblastoma cells from hyperosmotic induced programmed cell death. Journal of Cell Physiology 166 323-331.

Menouny M, Binoux M \& Babajko S 1997 Role of insulin-like growth factor binding protein-2 and its limited proteolysis in neuroblastoma cell proliferation: modulation by transforming growth factor- $\beta$ and retinoic acid. Endocrinology 138 683-690.

Nakao-Hayashi J, Ito H, Kanayasu T, Morita I \& Murota S 1993 Stimulatory effect of insulin and insulin-like growth factor I on migration and tube formation by vascular endothelial cells. Atherosclerosis 92 141-149.

Neuman T, Stephens RW, Salonen E-M, Timmusk T \& Vaheri A 1989 Induction of morphological differentiation of human neuroblastoma cells is accompanied by induction of tissue-type plasminogen activator. Journal of Neuroscience Research 23 274-281.

Ocrant I, Fay CT \& Parmelee JT 1990 Characterization of insulin-like growth factor binding proteins produced in the rat central nervous system. Endocrinology 127 1260-1267.

Pahlman S, Mamaeva S, Meyerson G, Mattsson MEK, Bjelfman C, Ortoft E \& Hammerling U 1990 Human neuroblastoma cells in culture: a model for neuronal cell differentiation and function. Acta Physiologica Scandinavica 592 25-37.

Pahlman S, Meyerson G, Lindgren E, Schalling M \& Johansson I 1991 Insulin-like growth factor-I shifts from promoting cell division to potentiating maturation during neuronal differentiation. Proceedings of the National Academy of Sciences of the USA 88 9994-9998.

Panagakos FS 1993 Insulin-like growth factor-I and -II stimulate chemotaxis of osteoblasts isolated from fetal rat calvaria. Biochimie $\mathbf{7 5}$ 991-994.

Recio-Pinto E \& Ishii DN 1988 Insulin and insulin-like growth factor receptors regulating neurite formation in cultured human neuroblastoma cells. Journal of Neuroscience Research 19 312-320.

Resnicoff M, Abraham D, Yutanawiboonchai W, Rotman HL, Kajstura J, Rubin R, Zoltick P \& Baserga R 1995 The insulin-like growth factor I receptor protects tumor cells from apoptosis in vivo. Cancer Research 55 2463-2469.

Roghani M, Hossenlopp M, Lepage P, Balland A \& Binoux M 1993 Isolation from human cerebrospinal fluid of a new insulin-like growth factor binding protein with a selective affinity for IGF-II. FEBS Letters 255 253-258.

Stewart CEH \& Rotwein P 1996 Growth, differentiation, and survival: multiple physiological functions for insulin-like growth factors. Physiology Review 76 1005-1026.

Stracke ML, Kohn EC, Aznavoorian SA, Wilson LL, Salomon D, Krutzsch HC, Liotta LA \& Schiffmann E 1988 Insulin-like growth factors stimulate chemotaxis in human melanoma cells. Biochemical and Biophysical Research Communications 153 1076-1083.

Stracke ML, Engel JD, Wilson LW, Rechler MM, Liotta LA \& Schiffman E 1989 The type 1 insulin-like growth factor receptor is a motility receptor in human melanoma cells. Journal of Biological Chemistry 264 21544-21549.

Sumantram VN \& Feldman EL 1993 Insulin-like growth factor I regulates c-myc and GAP-43 messenger ribonucleic acid expression in SH-SY5Y human neuroblastoma cells. Endocrinology 132 2017-2023.

Valinsky JE \& Le Douarin NM 1985 Production of plasminogen activator by migrating cephalic neural crest cells. EMBO Journal 4 1403-1406.

Vanderkerken K, Asosingh K, Braet F, Van Riet I \& Van Camp B 1999 Insulin-like growth factor-I acts as a chemoattractant factor for 5T2 multiple myeloma cells. Blood 93 235-241.

Van Obberghen E 1994 Signalling throughout the insulin receptor and the insulin-like growth factor-I receptor. Diabetologia 37 S125-S134.

Varani J, Orr W \& Ward PA 1978 A comparison of the migration patterns of normal and malignant cells in two assay systems. American Journal of Pathology 90 159-171.

Waters SB \& Pessin JE 1996 Insulin-receptor substrate 1 and 2 (IRS1 and IRS2): what a tangled web we weave. Trends in Cell Biology 6 $1-4$.

White MF \& Kahn CR 1994 The insulin signalling system. Journal of Biological Chemistry 269 1-4.

Received 31 August 1999

Accepted 11 November 1999 